\title{
Implications of Computational Thinking Knowledge Transfer for Developing Educational Interventions
}

\author{
Sandra Erika Gutiérrez-Núñez ${ }^{1}$ \\ (1) 0000-0002-4246-620X
}

\author{
Aixchel Cordero-Hidalgo ${ }^{1}$ \\ (D) 0000-0001-9927-0972 \\ Javier Tarango ${ }^{{ }^{*}}$ \\ (D) 0000-0002-0416-3400 \\ ${ }^{1}$ Autonomous University of Chihuahua, MEXICO \\ *Corresponding author: jtarango@uach.mx
}

Citation: Gutiérrez-Núñez, S. E., Cordero-Hidalgo, A., \& Tarango, J. (2022). Implications of Computational Thinking Knowledge Transfer for Developing Educational Interventions. Contemporary Educational Technology, 14(3), ep367. https://doi.org/10.30935/cedtech/11810

\section{ARTICLE INFO}

Received: 20 Dec 2021

Published: 12 Feb 2022

\section{ABSTRACT}

This article analyzes the way in which educators and researchers have pronounced themselves for incorporating computer programming in the K-12 curricula (basic and secondary education), recognizing its cognitive benefits in those who practice it, which can be useful in contexts other than computing, by influencing the development of higher order thinking skills and problem solving, both concepts integrated in the so-called computational thinking (CT). The proposal includes the vision of various authors, who conclude that the transfer of cognitive programming skills does not happen correctly given the prevalence of educational interventions designed under the belief that it occurs as an automatic and spontaneous process. The structure of the article is made up of three fundamental aspects: (1) historical account of the definition of knowledge transfer (KT), its main theoretical and classificatory taxonomies; (2) integration of existing definitions on $\mathrm{CT}$ and the way in which the formulation of various study plans in different countries has resulted; and (3) the investigation of different challenges and implications present in the $\mathrm{CT}$, as well as recommendations for its improvement, taking as a reference the results of experiments carried out in different academic fields, proposed in order to strengthen both the $\mathrm{KT}$ as well as the $\mathrm{CT}$.

Keywords: computational thinking, computer-like thinking, computational-informatics thinking, computational literacy, problem solving, computer science education

\section{INTRODUCTION}

The theoretical-practical development of computational thinking (CT) arose in an atypical way, arising first in industrial work environments, with later incorporation in higher education scenarios and descending to the rest of the educational levels until reaching basic education. thus being formally incorporated into the curriculum (Bocconi et al., 2016a; Sánchez-Vera, 2019). At present, governments around the world have sought to improve such curricular conditions, incorporating new compulsory knowledge of $\mathrm{CT}$, considering that its essence is directly related to the ability to solve problems (Li et al., 2020).

At present, the cognitive benefits of $\mathrm{CT}$ have been proven, observing that computer science programmers and students develop greater problem-solving skills (Salehi et al., 2020), especially in aspects of how to organize a process, as well as, recognize routines or repetitions, and develop a high capacity to identify errors in the operation of a system (Valverde-Berrocoso et al., 2015). Such cognitive training is known as systemic thinking, with which an interdisciplinary conceptual framework is built, used to observe a wide range of areas

Copyright $\odot 2022$ by authors; licensee CEDTECH by Bastas, CY. This article is an open access article distributed under the terms and conditions of the Creative Commons Attribution License (http://creativecommons.org/licenses/by/4.0/). 
that make up a whole (system) and its components (subsystems), applied not only to computing but also to scientific, organizational, personal and public systems (Sahaked \& Schechter, 2016).

Since $C T$ is considered a universal competence, whose training process must begin in childhood, thus awakening the analytical capacity, which becomes a fundamental part of school learning (Voogt et al., 2015). The integration of CT in a formal and compulsory way can only happen through its enclave in the curriculum, starting from basic education as a starting point and its future inclusion in the rest of the educational levels until reaching the higher level, but also, this can happen through informal and non-formal education to complement specific learning processes. Formal, informal and non-formal education demand the definition and implementation of CT-based interventions.

The objectives set to be achieved through the analysis presented in this article are concentrated in three approaches:

1. study the knowledge transfer (KT) as a determining action to achieve the effective use of knowledge, skills and attitudes from a teaching process, studying various theoretical and practical aspects that typify the different forms of KT of CT;

2. identify the cognitive processes that are involved in the development of $\mathrm{CT}$, as well as the formal educational actions that contribute to making this situation happen more appropriately, especially during basic education; and

3. analyze the implications of $\mathrm{CT}$ intervention processes in the field of basic education, taking as a reference the theory of cognitive constructivism, where the child constructs meanings from previous learning and experiences, which reinforce the structure of activities and training included in the curriculum.

\section{KNOWLEDGE TRANSFER AS A TEACHING AND LEARNING PROCESS}

KT is defined as the effective use of the knowledge, skills and attitudes acquired in an educational or training program (Peng et al., 2021; Shafie et al., 2020), becoming the preparation for future learning (Seufert et al., 2021), in two basic typifications: of training and learning, which are practically synonymous, where what really matters is the application of the knowledge acquired (Darling-Hammond et al., 2020). The KT contributes to making information portable, since it travels with the student to new locations and is applied in a novel, interesting and innovative way and happens in the form of meanings, expectations, generalizations, concepts or perceptions that are developed in previous situations and they are used in later ones (Vidal et al., 2021).

The classical positions of learning and KT can be expressed in three fundamental visions:

1. the doctrine of formal discipline, which maintains that the mental improvement resulting from learning is not specific, but occurs as a result of generalization to other domains, especially when applied in intellectually challenging subjects such as Latin and mathematics (Shin \& Bolkan, 2021);

2. the theory of identical elements, which maintains that training in one activity or function will only be transferred to another if they share common elements (Bonney et al., 2017); and

3. the theory of generalization, where the student abstracts for himself the general rules or principles of the situations he faces (Anderson \& Beavis, 2018; Barnett et al., 2020).

From these three positions arise different debates on KT between the defenders of the formal discipline and the defenders of the theory of the identical elements.

The typification of the forms of KT is still under debate; however, contemporary perspectives are based on the basis that their structure offers coincident or similar elements, in the sense that, in a traditional way, they are based on identifying specific stimuli, characteristics of the context, domain of knowledge, and psychological tasks (Bacon et al., 2021). Taking this as a reference, the main taxonomies in relation to KT are grouped into four:

1. By the type of knowledge that is transferred. This position corresponds to Saks et al. (2021) and is made up of various categories: content, declarative actions, procedural actions, metacognition, as well as literal, vertical, lateral, reverse, proportional, and relational learning. 


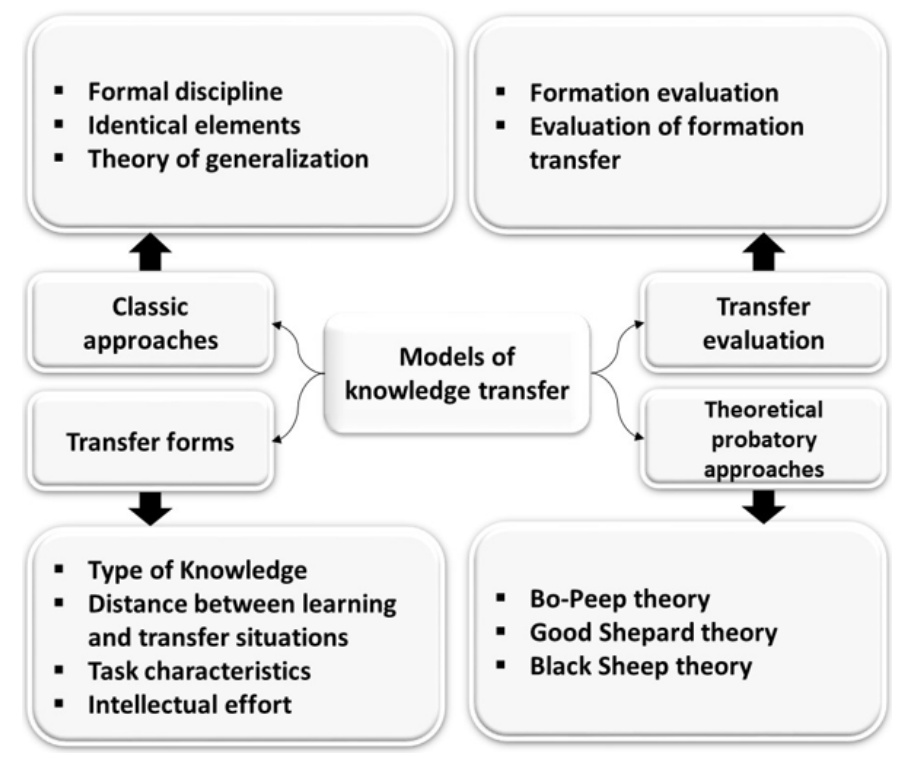

Figure 1. Classification of knowledge transfer models

2. By the distance between the learning situation and KT. Barnett et al. (2020) and When and Montalvo (2018) observe this distance, both in content and context. In content, distance is measured in three factors: specificity of what has been learned, type of performance, and memory demand; in context, it is measured by field of knowledge, physical, temporal, functional, and social context.

3. By the characteristics of the task. Alabau Gonzalvo et al. (2020) and Tarn and Yen (2020) distinguish three types of KT: (1) within the task (a task similar to the previous experience is carried out); (2) between tasks (applies to a superficially different situation, but functionally equivalent to the previous one); and (3) inventiveness (develops a new solution based on critical similarities and differences between the source and target tasks).

4. For the intellectual effort that they imply. Difference between low road KT and high road KT. The first involves the activation of repetitive routines practiced by stimulus conditions similar to those of the learning context; and the second, consists of a deliberate and laborious abstraction, as well as a search for connections (Ololube, et al., 2015). This type of KT classification is later included under the vision of Barnett et al. (2020) and When \& Montalvo (2018) under the names of near KT and far KT.

Among the models available to evaluate $\mathrm{KT}$, the following are identified:

1. the training evaluation model, which raises four criteria: reactions of the participants, learning, transfer and results (Alsalamah \& Callinan, 2021) and

2. the training transfer evaluation model, which involves three components: teaching or training inputs, teaching or training results, and KT conditions, the latter under two conditions or dimensions: generalization of learning and maintenance learning over a period of time (Ellington et al., 2015; Shafie et al., 2020).

Historically, in empirical studies, there have been three evidentiary theoretical positions that agglutinate the behavior of KT:

1. "Bo-peep" theory that states that KT will take place spontaneously and automatically (Kassab, 2021);

2. "Good shepherd" theory, which suggests that when KT is provoked, practiced and reflected upon is easy to achieve (Gordon \& Doyle, 2015; Salomon \& Perkins, 1989; van Peppen et al., 2021), these two positions generate two conditions: generalization and maintenance of acquired learning and the indicator of adaptability; and

3. "The black sheep" theory, based on the fact that KT is not presented and that it has become the black sheep of the studies of the educational community (Gordon \& Doyle, 2015; Zouhri \& Rateau, 2015; Chen \& Zhang, 2021).

All the KT study proposals are summarized in Figure 1. 
A wide range of factors can make or break the achievement of KT in the workplace. These factors have been treated in the literature in two general ways:

1. as predictor variables (Ellington et al., 2015; Shafie et al., 2020), manifested when a person is in the best mood for KT to occur when they are aware of acquiring meanings and skills that are widely applicable in learning and life (Römgens et al., 2020), and you must want to solve new problems and take risks and

2. as influential variables in KT (Sonhaji et al., 2020), where the influential variables with the strongest association with KT are: the learner's cognitive ability, scrupulousness and voluntary participation in training, support from the supervisor or the apprentice's colleagues, as well as the KT climate and the organizational restrictions in their work environment (Ornelas-Gutiérrez et al., 2016).

\section{COGNITIVE PROCESSES INVOLVED IN COMPUTATIONAL THINKING}

To better understand the construction of the definitions of CT, it becomes necessary to return to its origins. During the 20th century, with the emergence of computing and informatics, it was required to generate CT processes to program the first analog and digital computers. It was not until 1950 when the first programmable electronic computers were developed, thus initiating systematization processes based on CT, which were only necessary for the exercise of professionals related to computer systems (Denning \& Tedre, 2019). The subsequent development of CT happened when computing was incorporated into educational media, first at universities and later at lower academic levels. Initially, within higher education, where this phenomenon occurred from 1960 on and formal teaching properly began within the field of CT skills, its theoretical precedent being constructionism, a theory that links classical currents of learning with technology (Zapata-Ros, 2015).

The definition of CT shows a variety of interpretations, having as its main starting point, being considered a third competence within the school curriculum, after digital literacy and digital culture (Barr \& Stephenson, 2011; Lee et al., 2020; Li et al., 2020; National Research Council, 2010; Polanco Padrón et al., 2021; Polizzi, 2020). One of the best-known definitions was offered by Wing (2011), who affirms that CT is a problem-solving ability, based on certain specific skills and techniques that constitute the basis of digital culture and that "implies the design of systems and the understanding of human behavior, based on the fundamental concepts of computing "(p. 33); Aho (2012) simplified this definition as: the thought processes involved in formulating problems, so that "their solutions can be represented as steps and computational algorithms" ( $p$. 832); and Denning and Tedre (2019) proposed that CT includes mental skills and practices to design calculations where computers do work for us and as a consequence, explain and interpret the world as a complex of information processes.

In an attempt to offer conclusive conceptions, Román-González (2016) distinguishes three types of definitions of CT: (1) generic; (2) operational; and (3) educational and for use in school curricula. The most frequent definitions are considered operational, such as those proposed by Wing (2011) and those elaborated by The International Society for Technology in Education (CSTA \& ISTE, 2011). Followed by this type, are the offerings that are related to definitions for educational use, linked to conceptual frameworks, from which curricular and pedagogical alternatives have been developed, as is the case of the DigComp model created by the Joint Research Center of the European Commission for Science and Knowledge (Carretero Gómez et al., 2017).

With the passage of time, the training in $\mathrm{CT}$ processes jumps to other contexts, especially manifested in a variety of educational levels, completing a certain cycle through its inclusion upon reaching the K-12 educational level, where computing gained popularity by first time. All of this happened around the work of the Massachusetts Institute of Technology (MIT) in the 1980s, when it pioneered the idea of children developing procedural thinking through LOGO programming. Although the phrase and the notion of CT seems to be confused with the term computational literacy, in the reality of research and in current practice, the two phrases are used interchangeably (Lodi, 2020); however, in educational processes they must be separate both concepts, CT being the 'material' tools related to programming environments and computer literacy, the 'cognitive' and 'social' aspects experienced by the learner (Jacob \& Warschauer, 2018; Roncoroni Osio et al., 2020). 
In recent years, educators and researchers have spoken out for incorporating computer programming into K-12 curricula (basic and secondary education) (Lye \& Koh, 2014), while, at the level of institutions with broad influence on the global public policies, such as UNESCO, through its Institute of Statistics (UIS), have defined global reference frameworks on the contribution to digital literacy, which include both CT and computer programming as fundamental elements of the training of children and adolescents (Law et al., 2018). Both in the theoretical conceptualization of CT, and in the foundations that support the previous initiatives, there are multiple coinciding elements, which are concentrated in three global dimensions:

1. Foundations: Decomposition, pattern recognition, abstraction, and algorithms (Ríos Félix et al., 2020).

2. Categories: Data practices, modeling and simulation practices, computational problem solving practices, and systematic thinking practices (Cruz Castro et al., 2021; Weintrop et al., 2016).

3. Areas of competence: Empowerment, digital citizenship, knowledge construction, innovative design, CT, creative communication, and collaboration (ISTE, 2016).

The popularity of CT in the educational field is based on the affirmation of researchers and computer scientists that learning to program computers has various cognitive benefits (Lee et al., 2020), such as the improvement of thinking skills linked to creativity, reasoning, mathematical and planning skills (Scherer et al., 2019). The cognitive processes involved in CT, proposed by Shute et al. (2017), focus on the reformulation of situations, recursion, decomposition of problems, abstraction and systematic tests. Thus, when comparing basic CT with the demands to solve problems in the domains of the disciplines of science, technology, engineering, mathematics (STEM), Barr and Stephenson (2011), they concluded that programming skills, CT and resolution of problems are intertwined.

The results of empirical research in relation to $\mathrm{CT}$, based on $\mathrm{KT}$, are found in the essential part of education, which takes advantage of its applications in a flexible way of what has been learned (Anderson \& Beavis, 2018; Barnett et al., 2020). However, research in education indicates that KT is difficult and unlikely to occur automatically, especially between distant knowledge domains (Darling-Hammond et al., 2020). KT can happen through two forms of KT:

1. close (understood as the ability to solve problems similar to those learned during educational training) and

2. distant (ability to solve problems in situations widely different from those acquired during initial learning).

Denning (2017) affirms that the distant KT does not exist, which generates a wide controversy, in addition to this, Scherer (2016) and Scherer et al. (2019), highlight that in the current research there are many contradictory findings, since there is evidence both for and against KT processes in computer programming.

The consolidation of CT in basic education contexts is now integrated through reference frameworks and didactic resources based on government initiatives and specific institutions for its development in education, among which the following stand out:

1. Computer Science Teachers Association (CSTA), who raises CT standards for K-12 (ISTE, 2018).

2. European Commission for Science and Knowledge, who in 2013 proposed the European Digital Competence Framework (DigComp) program and in 2016, in addition, the DigComp 2.1 program (Kluzer \& Pujol Priego, 2018).

3. British Computer Society, who, in alliance with the BBC, applies a series of techniques for CT across KS3 / 4 levels in infants in the first grades of school (BBC-UK, 2015).

4. National Science Foundation (NSF, 2019) offering the STEM + Computing K-12 Education program in 2016 and in 2017 from the National Science and Technology Council (NSTC), both with funding from the CS for All Fund.

5. The Latin American initiative called 'Learning for the Future' of Foundation Chile since 2001 (Fundación Chile [Chile Foundation], 2017), which is a scenario to favor the digitization and development of actors of the educational system with skills to adapt to the society of the knowledge. 
6. The @prende.mx program of the Mexican government that proposes a Framework of Reference for Computational Thinking in Basic Education, which proposes the development of digital skills in children, especially those with low economic resources (Cárdenas Peralta, 2018).

In addition to institutional or governmental initiatives, there are campaigns and impulses of various NGOs that promote the informal learning of computer skills from an early age, such as: CS Unplugged, Bebras, Scratch, PBS KIDS Scratch Jr., Minecraft, Kodable, codeSpark Academy, Sphero, Khan Academy, Code Club, Code Avengers, EU Code Week, Code.org: The Hour of Code, CoderDojo, Code Club, Made with Code, European Coding Initiative, Computing at School, CompuThink, Code for Change, Google CS First, Epic Queen, Cuantrix.mx, Programamos.es, Program.ar, among others (Bocconi et al., 2016b).

\section{IMPLICATIONS OF COMPUTATIONAL THINKING IN INTERVENTION PROCESSES IN BASIC EDUCATION}

From the position of cognitive constructivism, the purpose of education is to allow students to generate new knowledge through a process of construction of meanings with an emphasis on active discovery, based on previous learning and past experiences (Baker et al., 2019), so that KT is at the very heart of education, since it takes advantage of the flexible application of what has been learned (Barnett et al., 2020; DarlingHammond et al., 2020).

Currently, learning and KT are considered conceptually indistinguishable, the latter being one of the six basic and emerging fields in which educational research needs to advance in the 21st century. Research in the field indicates that $\mathrm{KT}$ can be explicitly promoted by employing instructional strategies that reinforce a strong understanding of knowledge (Ambrose et al., 2014). According to these authors, a specific methodological proposal is that of 'teaching to transfer', which comprises two specific techniques:

1. 'hugging', which means teaching to better meet the conditions of similarity of situations by way of transference close or low road and

2. 'building bridges', seeking to promote learning situations, different from those presented in original situations, seeking distant KT or high road, based on abstraction and reflection in a structured and mediated way.

The achievement of the far or high way $\mathrm{KT}$ is complex and with a low possibility of achieving significant learning. For example, it is known that the simple teaching of elementary programming does not promote cognitive skills that require further development of experience and varied applications. In addition, achieving $\mathrm{KT}$ implies the application of certain skills to recognize the similarity between two situations and promote the KT of different types of knowledge: activate the necessary knowledge and apply it correctly (Saks et al., 2020). The necessary interventions in distant KT or high road, require achieving depth in the understanding of the concepts, as well as their generalization, which implies changing environments and building relationships, instead of reproducing the existing relationships between regular or common tasks (Gysin \& Brovelli, 2021).

Both in the KT processes, of the near or low type or of the far or high path type, require the student to develop flexible reasoning, which is why it is suggested to use a wide range of strategies for different situations, such as: construction of explanations, modeling, inquiry and project-based approaches and problem solving (Alabau Gonzalvo et al., 2020). When the expectation is that students manage to transfer knowledge to new situations, it will be necessary to start by establishing conceptual links, both within and between thematic disciplines (Green, 2022) and to promote KT between domains, contexts from all viable fields should be included for learning a body of knowledge and its application in real situations.

Other strategies that are widely recommended to contribute to CT, according to Green (2022) and Lodi (2020), are based on providing students with the following:

1. adequate time to explore the underlying concepts and generate connections;

2. the proportion of a variety of worked examples with a detailed and explained solution;

3. participation in concrete activities dependent on the context and balanced with those of transcontextualized abstract knowledge; 
4. encourage students to make structured comparisons of different problems, looking for deep and significant characteristics;

5. cause the applicability conditions of one or another methodology to be discussed in hypothetical scenarios;

6. ask students to look for contexts in which a particular skill can be applied, to abstract and extrapolate principles from different real-world situations; and

7. generate situations of self-control over learning (metacognition) to participate in 'deliberate practices'.

Feedback to students becomes essential in the development of CT, especially about their learning process, as well as in the guide in different and precise indications, thereby encouraging them to remember a different exercise in similar strategies, thus promoting analogical reasoning and make them articulate causal relationships. Since most teachers prepare their classes with an eye toward a list of content objectives, Zohar and Barzilai (2015) suggest including an additional list of CT objectives as well. The evidence suggests that KT is more effective in an instruction in which the teacher guides the student (direct instruction), compared to an instruction in which the student discovers by himself what he has to learn (discovery learning) (Rastle et al., 2021). In general, it has been proven that some guidance from the teacher can dramatically improve the result of the $\mathrm{KT}$.

The strategies to adequately achieve the $\mathrm{KT}$ processes towards $\mathrm{CT}$, take as a basis the initial learning situations proposed by the teacher, where it is recommended:

1. look for similarity between what is taught and the KT situation that is desired achieve;

2. provide appropriate experiences;

3. offer a variety of examples to support the concepts and principles being taught; and

4. identify the important characteristics of the task for the understanding of the general principles. In addition, it becomes essential to conduct the classes in a way that emphasizes the students' full attention in the higher order processes of problem solving (Wenzelburger, 2020).

The application of experiments in educational processes and the promotion of $\mathrm{CT}$, make it possible to point out the following activities as essential to achieve it:

1. Aim to understand and apply the content (Alabau Gonzalvo, 2020).

2. Maximize the socio-cognitive function of group work in the classroom (formulate hypotheses and test them; explain, interpret and design experiments or devices; justify decisions and reason them critically (Sotiriou et al, 2020).

3. Develop adequate mental representations (Egan, 2020; Solaz-Portolés \& Sanjosé, 2008).

4. Design experiences so that students test their ideas in a rigorous way, for this, the didactic units must be designed thinking both about the specific contents of the subject (concepts, theories and laws), as well as the development of cognitive skills, based on the process of analysis, synthesis, inference, abstract reasoning, among others (Alabau Gonzalvo et al., 2020), favoring learning in multiple contexts.

5. Focus the understanding of the contents and the design of collaborative strategies where the action must be justified, carrying out a grading in the KT level required in solving the problems that are planted (Li et al., 2020; Macagno \& Apanta, 2019).

6. Teach students to encode information about a problem, a situation that should be characterized by the way in which information is selected from the text, to later separate the relevant information from that which is not (Lee et al., 2020).

\section{CONCLUSIONS}

Advances in the study of CT in KT have shown extensive development, moving from conceptualization to validation of methodologies, however, achieving in reality the purposes proposed in its successful application when required, is a problem of the utmost importance for educational systems. 
The proposals of various taxonomies, which offer possible ways to interpret the scope of $\mathrm{CT}$, still remain unsatisfied given the need for a pedagogical approach, especially when it lacks the statement of explicit objectives for the achievement of CT and KT.

The proposed ideal, essentially focuses on achieving a metacognitive thinking of the student about their mental processes in each learning situation, in this way, the objective of KT would happen as a process of logical, inductive, deductive and creative reasoning, especially abductive (reasoning descriptive of a fact or phenomenon to arrive at a hypothesis). The process described above takes place within the human brain as a result of exposure to a certain experience, under the possibility that the student acquires consciousness, being able to replicate it and adapt it to future experiences.

The preparation of the student to acquire certain skills and identify patterns of behavior, lies in the difficulty of making him recognize the similarities and differences between such patterns and get him to express his cognitive process. The problem proposed in the KT is to make the student aware that when facing a basic problem, he is able to activate a series of steps and thought processes, which led him to solve similar problems previously experienced. This would represent metacognition and not learning the mechanical processes on which most educational programs are based.

The search for KT projected in cognitive benefits of programming for the achievement of CT requires certain conditions such as: (i) ensuring that the student has sufficient prior knowledge of programming and understands the elements of KT (objective, purpose and design of a mental plan) and (ii) apply deliberate and laborious abstraction in search of concepts, similarities and differences between previous and current situations. The student is expected to achieve this condition, which gives them the possibility of analyzing strategies based on their experience and selecting the most suitable ones. This would be the practice of KT under the confidence in its conclusions and in the training of working memory.

$\mathrm{KT}$ is consolidated over time, that is why curricular programs related to CT must be structured from the first school grades, where concepts, operations and programming procedures are deepened, with a wide repertoire of connections and where the application of the prior knowledge in new situations, observing agility in task execution times.

The search for transferring the cognitive processes of CT implies developing educational interventions constituted by declarative-procedural-attitudinal knowledge, according to the age and cognitive maturation of the group receiving the training program, as well as giving enough time for the concepts to be able to be assimilated and allow extensive practice in KT programming and thinking (both near or low path and far or high path) at its different levels of content and context. In these processes, the student's motivation to program and transfer is decisive in the success of the program activities, therefore, it becomes necessary to determine the initial motivation level and maintain the design of interesting and creative practices, which increase the level motivation-curiosity of the student and thus achieving an adequate KT.

\section{Recommendations for Future Researchers}

The research needs that arise in the future on $\mathrm{KT}$, it is recommended to focus on the following aspects:

1. Look for mechanisms to answer the questions that prevail around the ideal duration of an educational or training program for work to achieve the acquisition of knowledge and training in $\mathrm{KT}$, before presenting the participating subject with the challenge of using such knowledge and skills in other contexts.

2. Develop maps or action routes that specify the stages that the mental process of knowledge acquisition must complete, until such time as these become a resource that is always accessible to the student, so that they can be used in any situation where they result. relevant, that is, until they are actually able to use the KT.

3. Carry out empirical research in order to test KT strategies that offer results in relation to time-efficiency, as well as on the combinations of strategies for the different levels of KT proposed by the taxonomies included in this article.

\section{Research Limitations}

Being a theoretical proposal, this article has limitations, as follows: 
1. Lack of empirical data without a concrete contribution to experimental research; therefore, it is unlikely to demonstrate the reliability of the approaches in reality.

2. The topic of the KT has not resulted from the interest of both the government and the educational institutions, both in the training processes and in the subsequent activities of their students when they graduate. It can be said that the topic of KT is not part of the current educational research agenda and the mechanisms to achieve it have been few in recent years, so the topic studied may have less impact.

3. The theoretical approach offers a regional vision on the topic of KT, regularly focused on the Latin American context in which the authors operate; therefore, it is not necessarily the condition that occurs in other regions of the world.

Author contributions: All authors were involved in concept, design, collection of data, interpretation, writing, and critically revising the article. All authors approve final version of the article.

Funding: The authors received no financial support for the research and/or authorship of this article.

Declaration of interest: Authors declare no competing interest.

Data availability: Data generated or analyzed during this study are available from the authors on request.

\section{REFERENCES}

Aho, A. V. (2012). Computation and computational thinking. Computer Journal, 55(7), 832-835. https://doi.org/10.1093/comjnl/bxs074

Alabau Gonzalvo, J., Solaz-Portoles, J. J., \& Sanjosé López, V. (2020). Relación entre creencias sobre resolución de problemas, creencias epistemológicas, nivel académico, sexo y desempeño en resolución de problemas: un estudio en educación secundaria [Relationship between problem-solving beliefs, epistemological beliefs, academic level, gender, and problem-solving performance: a study in secondary education]. Revista Eureka Sobre Enseñanza y Divulgación de las Ciencias [Eureka Magazine on Teaching and Dissemination of Sciences], 17(1), 1-16. https://doi.org/10.25267/Rev_Eureka_ensen_divulg_cienc.2020. v17.i1.1102

Alsalamah, A., \& Callinan, C. (2021). Adaptation of Kirkpatrick's four-level model of training criteria to evaluate training programmes for head teachers. Education Sciences, 11(3), 116. https://doi.org/10.3390/ educsci11030116

Ambrose, S. A., \& Lovett, M. C. (2014). Prior knowledge is more than content: Skills and beliefs also impact learning. In V. A. Benassi, C. E. Overson, \& C. M. Hakala (Eds.), Applying science of learning in education: Infusing psychological science into the curriculum (pp. 7-19). Society for the Teaching of Psychology.

Anderson, M., \& Beavis, A. (2018). Teaching for learning transfer: A literature review. Victorian Curriculum and Assessment Authority.

Bacon, E., Williams, M. D., \& Davies, G. H. (2021). On the combinatory nature of knowledge transfer conditions: A mixed method assessment. Information Systems Frontiers.https://doi.org/10.1007/s10796-021-10127-7

Baker, L., Ng, S., \& Friesen F. (2019). Paradigms of education: An online supplement. www. paradigmsofeducatio Barnett, S., Rindermann, H., Williams, W., \& Ceci, S. (2020). Society and Intelligence. In R. Sternberg (Ed.), The Cambridge handbook of intelligence (pp. 964-987). Cambridge University Press. https://doi.org/10.1017/ 9781108770422.041

Barr, V., \& Stephenson, C. (2011). Bringing computational thinking to K-12: What is involved and what is the role of the computer science education community? ACM Inroads, 2(1), 48-54. https://doi.org/10.1145/ 1929887.1929905

BBC-UK. (2015). KS3 Computer science: Introduction to computational thinking. https://www.bbc.co.uk/bitesize/ subjects/zvc9q6f

Bocconi, S., Chioccariello, A., Dettori, G., Ferrari, A., \& Engelhardh, K. (2016a). Developing computational thinking in compulsory education: Implications for policy and practice. European Commission.

Bocconi, S., Chioccariello, A., Dettori, G., Ferrari, A., Engelhardt, K., Kampylis, P., \& Punie, Y. (2016b). Exploring the field of computational thinking as a 21st century skill (pp. 4725-4733). In Proceedings of the EDULEARN16, Barcelona, España. https://doi.org/10.21125/edulearn.2016.2136 
Bonney, E., Jelsma, L. D., Ferguson, G. D., \& Smits-Engelsman, B. (2017). Learning better by repetition or variation? Is transfer at odds with task specific training? Plos One, 12(3), e0174214. https://doi.org/ 10.1371/journal.pone.0174214

Cárdenas Peralta, M. C. (2018). Pensamiento computacional: Educación básica. Marco referencial_(@prende 2.0) [Computational thinking: Basic education. Referential framework (@prende 2.0)]. Gobierno de México. https://bit.ly/cardenasFramework

Carretero Gómez, S., Vuorikari, R., \& Punie, Y. (2017). DigComp 2.1: The digital competence_framework for citizens with eight proficiency levels and examples of use. EUR scientific and technical research reports. Publications Office of the European Union.

Chen, S., \& Zhang, C. (2021). What happens to a black sheep? Exploring how multilevel leader-member exchange differentiation shapes the organizational altruism behaviors of low leader-member exchange minority. Group \& Organization Management, 46(6), 1073-1105. https://doi.org/10.1177/ 1059601121998584

Cruz Castro, L. M., Magana, A. J., Douglas, K. A., \& Bouti, M. (2021). Analyzing students' computational thinking practices in a first-year engineering course. IEEE Access, 9, 33041-33050. https://doi.org/10.1109/ACCESS. 2021.3061277

CSTA \& ISTE. (2011). Operational definition of computational thinking for K-12 education. https://www.csteachers.org/page/about-csta-s-k-12-nbsp-standards

Darling-Hammond, L., Flook, L., Cook-Harvey, C., Barron, B., \& Osher, D. (2020) Implications for educational practice of the science of learning and development. Applied Developmental Science, 24(2), 97-140. https://doi.org/10.1080/10888669.2018.1537791

Denning, P. J. (2017). Remaining trouble spots with computational thinking. Communications of the ACM, 60, 33-39. https://doi.org/10.1145/2998438

Denning, P. J., \& Tedre, M. (2019). Computational thinking. MIT Press. https://doi.org/10.7551/mitpress/ 11740.001 .0001

Egan, J. P. (2020). Beyond the afterglow: Effective transfer of learning through instructional design. Teaching and Learning Inquiry, 8(1), 173-186. https://doi.org/10.20343/teachlearninqu.8.1.12

Ellington, J. E., Surface, E. A., Blume, B. D., \& Wilson, M. A. (2015). Foreign language training transfer: Individual and contextual predictors of skill maintenance and generalization. Military Psychology, 27(1), 36-51. https://doi.org/10.1037/mil0000064

Fundación Chile [Chile Foundation]. (2017). Pensamiento computacional [Computational thinking]. Gobierno de Chile, Ministerio de Educación [Ministry of Education]. https://fch.cl/noticia/25171

Gordon, B., \& Doyle, S. (2015). Teaching personal and social responsibility and transfer of learning: Opportunities and challenges for teachers and coaches. Journal of Teaching in Physical Education, 34, 152161. https://doi.org/10.1123/jtpe.2013-0184

Green, C., Molloy, O., \& Duggan, J. (2022). An empirical study of the impact of systems thinking and simulation on sustainability education. Sustainability, 14(394), 1-30. https://doi.org/10.3390/su14010394

Gysin, D., \& Brovelli, D. (2021). Use of knowledge pieces and context features during the transfer process in physics tasks. International Journal of Science Education, 43(13), 2108-2126. https://doi.org/ 10.1080/09500693.2021.1952334

ISTE. (2016). Standards for students. https://www.iste.org/standards

ISTE. (2018). Computational thinking meets student learning: Extending the ISTE standards. International Society for Technology in Education. https://www.iste.org/standards/foreducators

Jacob, S. R., \& Warschauer, M. (2018). Computational thinking literacy. Journal of Computer Science Integration, 1(1), 1-25. https://doi.org/10.26716/jcsi.2018.01.1.1

Kassab, K. (2021). An investigation of transfer of learning in an English-for-specific-academic writing course: Teaching for transfer. International Journal of Linguistics, Literature and Translation, 4(2), 172-184. https://doi.org/10.32996/ijllt

Kluzer, S., \& Pujol Priego, L. (2018). DigComp into action-get inspired, make it happen. In S. Carretero Gomez, Y. Punie, R. Vuorikari, M. Cabrera Giraldez, \& W. O'Keefe (Eds.), JRC Science for Policy Report, EUR 29115 $E N$. Office of the European Union, Luxembourg. https://doi.org/10.2760/112945 
Law, N., Woo, D., De la Torre, J., \& Wong, G. (2018). A global framework of reference on digital literacy skills for indicator 4.4.2. http://uis.unesco.org/sites/default/files/documents/ip51-global-framework-referencedigital-literacy-skills-2018-en.pdf

Lee, I., Grover, S., Martin, F., Pillai, S., \& Malyn-Smith, J. (2020). Computational thinking from a disciplinary perspective: Integrating computational thinking in K-12 science, technology, engineering, and mathematics education. Journal of Science Education and Technology, 29, 1-8. https://doi.org/ 10.1007/s10956-019-09803-w

Li, Y., Schoenfeld, A. H., DiSessa, A. A., Graesser, A. C., Benson, L.C., English, L. D., \& Duschl, R. A. (2020). Computational thinking is more about thinking than computing. Journal for STEM Education Research, 3 , 1-18. https://doi.org/10.1007/s41979-020-00030-2

Lodi, M. (2020). Introducing computational thinking in K-12 education: Historical, epistemological, pedagogical, cognitive, and affective aspects. https://hal.inria.fr/tel-02981951/document

Lye, S. Y., \& Koh, J. H. L. (2014). Review on teaching and learning of computational thinking through programming: What is next for K-12? Computers in Human Behavior, 41, 51-61. https://doi.org/ 10.1016/j.chb.2014.09.012

Macagno, F., \& Apanta, C. R. (2019). The dimensions of argumentative texts and their assessment. Studia Paedagogica [Studies in Pedagogy], 24(4), 11-44. https://doi.org/10.5817/SP2019-4-1

National Research Council (2010). Preparing teachers: Building evidence for sound policy. The National Academies Press.

National Science Foundation (NSF). (2019). TEM + computing $K-12$ education (STEM $+C$ ). https://www.nsf.gov/funding/pgm_summ.jsp?pims_id=505006

Ololube, N.P., Ajuru, I., James, P., \& Makewa, L.N. (2015). Handbook of research on enhancing teacher education with advanced instructional technologies. Information Science Reference. https://doi.org/10.4018/978-14666-8162-0

Ornelas-Gutiérrez, D., Cordero Arroyo, G., \& Cano García, E. (2016). La transferencia de la formación del profesorado universitario: Aportaciones de la investigación reciente [The transfer of university teacher training: Contributions of recent research]. Perfiles Educativos [Educational Profiles], 38(154), 57-75. https://doi.org/10.22201/iisue.2448167e.154.57662

Peng, M. Y.-P., Feng, Y., Zhao, X., \& Chong, W. (2021). Use of knowledge transfer theory to improve learning outcomes of cognitive and non-cognitive skills of university students: Evidence from Taiwan. Frontiers in Psychology, 12, 1-12. https://doi.org/10.3389/fpsyg.2021.583722

Polanco Padrón, N., Ferrer Planchart, S., \& Fernández Reina, M. (2021). Aproximación a una definición de pensamiento computacional [Approach to a definition of computational thinking]. Revista Iberoamericana de Educación a Distancia [Ibero-American Journal of Distance Education], 24(1), 5576.https://doi.org/10.5944/ried.24.1.27419

Polizzi, G. (2020). Digital literacy and the national curriculum for England: Learning from how the experts engage with and evaluate online content. Computer \& Education, 152, 1-13. https://doi.org/10.1016/ j.compedu.2020.103859

Rastle, K., Lally, C., Davis, M. H., \& Taylor, J. S. H. (2021). The dramatic impact of explicit instruction on learning to read in a new writing system. Psychological Science, 32(4), 471-484. https://doi.org/10.1177/ 0956797620968790

Ríos Félix, J. M., Zatarin Cabada, R., Barrón Estrada, M. L., \& Favela Vera, J. (2020). An intelligent learning environment for computational thinking. Computación y Sistemas [Computing and Systems], 24(3), 11991210. https://doi.org/10.13053/cys-24-3-3480

Román-González, M. (2016). Test de pensamiento computacional: Principios de diseño, validación de contenido y análisis de ítems [Computational thinking test: Design principles, content validation, and item analysis]. In M. A. Murga Menoya (Ed.), Perspectivas y avances de la investigación [Research prospects and advances] (pp. 279-302). UNED.

Römgens, I., Scoupeb, R., \& Beausaert, S. (2020). Unraveling the concept of employability, bringing together research on employability in higher education and the workplace. Studies in Higher Education, 45(12), 2588-2603. https://doi.org/10.1080/03075079.2019.1623770

Roncoroni Osio, U., Lavín, E., \& Bailón Maxi, J. (2020). Computational thinking: Digital literacy without computers. Icono 14 [/con 14], 18(2), 379-405. https://doi.org/10.7195/ri14.v18i2.1570 
Sahaked, H., \& Schechter, C. (2016). Source of systems thinking in school leadership. Journal of School Leadership, 26, 468-494. https://doi.org/10.1177/105268461602600304

Saks, K., Ilves, H., \& Noppel, A. (2021). The impact of procedural knowledge on the formation of declarative knowledge: How accomplishing activities designed for developing learning skills impacts teachers' knowledge of learning skills. Education Sciences, 11(598), 1-15. https://doi.org/10.3390/educsci11100598

Salehi, S., Wang, K. D., Toorawa, R., \& Wieman, C. (2020). Can majoring in computer science improve general problem-solving skills? In Annual Conference on Innovation and Technology in Computer Science Education (pp. 156-161). https://doi.org/10.1145/3328778.3366808

Salomon, G., \& Perkins, D. N. (1987). Transfer of cognitive skills from programming: When and how? Journal of Educational Computing Research, 3(2), 149-169. https://doi.org/10.2190/6F4Q-7861-QWA5-8PL1

Sánchez-Vera, M. M. (2019). El pensamiento computacional en contextos educativos: Una aproximación desde la tecnología educativa [Computational thinking in educational contexts: An approach from educational technology]. Research in Education and Learning Innovation Archives, 23, 24-39. https://doi.org./10.7203/ realia.23.15635

Scherer, R. (2016). Learning from the past-The need for empirical evidence on the transfer effects of computer programming skills. Frontiers in Psychology, 7, 1-4. https://doi.org/10.3389/fpsyg.2016.01390

Scherer, R., Siddiq, F., \& Sánchez-Viveros, B. (2019). The cognitive benefits of learning computer programming: A meta-analysis of transfer effects. Journal of Educational Psychology, 111(5), 764792. https://doi.org/10.1037/edu0000314

Seufert, S., Guggemos, J., \& Sailes, M. (2021). Technology-related knowledge, skills, and attitudes of pre- and in-service teachers: The current situation and emerging trends. Computers in Human Behavior, 115, 1-11. https://doi.org/10.1016/j.chb.2020.106552

Shafie, S., Majid, F. A., Damio, S. M., \& Hoon, T. S. (2020). Evaluation on the face and content validity of a soft skills transfer of training instrument. International Journal of Academic Research in Business and Social Sciences, 10(10), 1054-1065. https://doi.org/10.6007/IJARBSS/v10-i10/8267

Shin, M., \& Bolkan, S. (2021) Intellectually stimulating students' intrinsic motivation: The mediating influence of student engagement, self-efficacy, and student academic support. Communication Education, 70(2), 146-164. https://doi.org/10.1080/03634523.2020.1828959

Shute, V. J., Sun, C., \& Asbell-Clarke, J. (2017). Demystifying computational thinking. Educational Research Review, 22, 142158. https://doi.org/10.1016/j.edurev.2017.09.003

Solaz-Portolés, J. J., \& Sanjosé, V. (2008). Types of knowledge and their relations to problem solving in science: Directions for practice. Educational Sciences Journal, 6, 105-112. http://bit.ly/TypesofKnowledge

Sonhaji, I., Wijayati, D. T., Soedjarwo, S., Supardam, D., Setiyo, S., \& Muharlisiani, S. T. (2020). Factors analysis that affecting "knowledge sharing" in t-vet instructors at Aviation Polytechnic of Surabaya. Talent Development \& Excellence, 12(1), 5317-5328.

Sotiriou, S. A., Lazourdis, A., \& Bogner, F. X. (2020). Inquiry-based learning and e-learning: How to serve high and low achievers. Smart Learning Environments, 7(29), 1-15. https://doi.org/10.1186/s40561-020-00130$x$

Tarn, D., \& Yen, D. (2020). Task characteristics and knowledge management performance: Model development and scale construction. Knowledge Management Research \& Practice. https://doi.org/10.1080/14778238. 2020.1785346

Valverde-Berrocoso, J., Fernández-Sánchez, M. R., \& Garrido-Arroyo, M. C. (2015). El pensamiento computacional y las nuevas ecologías del aprendizaje [Computational thinking and new learning ecologies]. Revista de Educación a Distancia [Distance Education Magazine], 46(3). https://doi.org/ 10.6018/red/46/3

van Peppen, L. M., Verkoeijen, P. P. J. L., Heijltjes, A. E. G., Janssen, E. M., \& van Gog, T. (2021). Enhancing students' critical thinking skills: Is comparing correct and erroneous examples beneficial? Instructional Science (preprint). https://doi.org/10.1007/s11251-021-09559-0

Vidal, P., De Moura, J., Novo, J., \& Ortega M. (2021). Multi-stage transfer learning for lung segmentation using portable X-ray devices for patients with COVID-19. Expert Systems with Applications, 173, 114677. https://doi.org/10.1016/j.eswa.2021.114677 
Voogt, J., Fisser, P., Good, J., Mishra, P., \& Yadav, A. (2015). Computational thinking in compulsory education: Towards an agenda for research and practice. Education and Information Technologies, 20, 715-728. https://doi.org/10.1007/s10639-015-9412-6

Weintrop, D., Beheshti, E., Horn, M., Orton, K., Jona, K., Trouille, L., \& Wilensky, U. (2016). Defining computational thinking for mathematics and science classrooms. Journal of Science Education and Technology, 25(1), 127-147. https://doi.org/10.1007/s10956-015-9581-5

Wenzelburger, E. (2020). La transferencia en el aprendizaje [Transfer in learning]. http://publicaciones.anuies.mx/acervo/revsup/res061/art4.htm

When, U., \& Montalvo, C. (2018). Knowledge transfer dynamics and innovation: Behaviour, interactions and aggregated outcomes. Journal of Cleaner Production, 171, S56-S68. https://doi.org/10.1016/ j.jclepro.2016.09.198

Wing, J. M. (2011). Computational thinking. In 2011 IEEE Symposium on Visual Languages and Human-Centric Computing (VL/HCC 2011) (pp. 33-35). IEEE. https://doi.org/10.1109/VLHCC.2011.6070404

Zapata-Ros, M. (2015). Pensamiento computacional: Una nueva alfabetización digital [Computational thinking: A new digital literacy]. Revista de Educación a Distancia [Distance Education Magazine], 46, 1-47. https://doi.org/10.6018/red/45/4

Zohar, A., \& Barzilai, S. (2015). Metacognition and teaching higher order thinking (HOT) in science education: Students' thinking, teachers' knowledge, and instructional practices. In R. Wegerif, L. Li, \& J. Kaufman (Eds.), Routledge international handbook of research on teaching thinking (pp. 229-242). Routledge.

Zouhri, B., \& Rateau, P. (2015). Social representation and social identity in the black sheep effect. European Journal of Social Psychology, 45, 669-677. https://doi.org/10.1002/ejsp.2138 